\title{
Designing the Interior of Candi Loka Ngawi Restaurant by Applying the Batik Jamus Tea Motif Theme
}

\author{
Anam Nur Cahyono ${ }^{\mathrm{a}, 1}$, Indarto ${ }^{\mathrm{a}, 2^{*}}$ \\ ${ }^{a}$ Faculty of Art and Design, Institut Seni Indonesia, Surakarta, Indonesia \\ 1 anamnurcahyono@gmail.com; ${ }^{2}$ interior.hanindart@gmail.com \\ * Corresponding Author
}

Received 2020-04-16, accepted 2020-05-10, published 2021-04-16

\begin{abstract}
The application of the Jamus Tea motif batik theme in the interior design of Candi Loka Restaurant in Ngawi is an effort to accommodate the needs of visitors to the Jamus Tea Plantation tourism object to enjoy the processed tea. This work aims to create a comfortable interior design of Candi Loka Restaurant and apply a contemporary style. In this work, the theme of the Jamus Tea batik motif is applied through the Kurtz programming method. The result of this work is the interior design of Candi Loka Restaurant, which includes lobby facilities, dining area, teashop, workshop and education area, management office, kitchen, rest area, warehouse, prayer room, and toilet. The results of this work can be a reference for interior designers in designing contemporary interior concepts based on local wisdom.
\end{abstract}

\section{KEYWORDS}

Interior

Restaurant

Contemporary

Candi Loka

Tea

This is an openaccess article under the CC-BY-SA

license

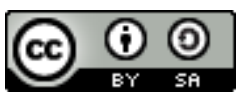

\section{Introduction}

Tea plantation is one aspect of the agricultural sector profitable in Indonesia, given its strategic geographic location. Indonesia is the fifth largest tea-producing country after India, China, Sri Lanka, and Kenya (Alatas and Wan Sulong 2020). In 2002, Indonesia's total tea production reached 172,790 tons, or 5.7 percent of the world's total tea production, which reached 3,062,632 tons. So it is not surprising that several highlands and mountains in Indonesia have tea plantations as income from the agricultural sector. One of the tea plantations developing on the island of Java, especially in East Java, is the Jamus Tea Plantation, Ngawi Regency. This tea garden is one of the tea gardens with relatively good quality. The Jamus Tea Plantation is under the management of a company called P.T. Loka Temple. This tea plantation is lovely and relaxed, in the morning, the temperature can reach $20^{\circ} \mathrm{C}-23^{\circ} \mathrm{c}$, and during the day $25^{\circ} \mathrm{C}-26^{\circ} \mathrm{c}$. This tea garden's beauty is now being developed as a tourist attraction that can attract tourists to enjoy its beauty. Geographically, Jamus Tea Plantation is located on the northern slopes of Mount Lawu and is at an altitude of $800 \mathrm{~m}$ above sea level. Administratively it is located in Girikerto Village, Sine District, Ngawi Regency (Pujiasmanto et al. 2021). The distance between the Jamus Tea Plantation and the subdistrict capital is $9 \mathrm{~km}$ and can be reached in about 20 minutes. Meanwhile, the distance to the district capital is $48 \mathrm{~km}$, which can be reached in about one hour using land transportation. This can be seen in the Ngawi district spatial planning book (Hermawan and Sholihah 2020).

Ngawi Regency is located in the western region of East Java province, directly adjacent to Central Java. Ngawi Regency is $1,295.98 \mathrm{~km} 2$, of which about 39 percent or about $504.8 \mathrm{~km} 2$ are rice fields. Based on the 2004 regional regulation, the Ngawi region is divided into 19 districts and 217 villages, of which 4 of the 217 villages are in the form of Kelurahan. Geographically, the regency is located in the position of 7o21'-7o31 'south latitude and 110o10' - 111o40 'east longitude. This administrative location is very profitable because it is in the Ngawi tourism development route, namely the Kenebejo route. The Kenebejo Line is a tourist route that includes Kedunggalar District, Sine District, Ngrambe District, and Jogorogo District. These areas have several tourist objects that the Ngawi Regency government is currently 
developing in collaboration with other agencies, PT Candi Loka, in the Jamus Tea plantation. It is recorded that the number of visitors to this tourist attraction continues to increase every year and the development of the Ngawi district tourism office (Syahbudin et al. 2019).

The number of tourists visiting the Jamus Tea Plantation tourism object in 2009 was 548,054 people, in 2010 as many as 639,741 people, in 2011 as many as 618,751 people, in 2012 there were 703,658 people, in 2013 as many as 853,712 people and in 2014 as many as 945,576 people (Pujiasmanto et al. 2021). The Jamus Tea Plantation, as one of the large plantation units in the Ngawi district of East Java province, is a legacy of the Dutch colonial era in 1866. Initially, this plantation was pioneered by Van Rappat, who came from the Dutch who carried out colonialism to find natural resources and used it for the benefit of their country. After the Japanese came to Indonesia, the Japanese took over the management, and most of the tea plants were replaced with secondary crops for consumption by the Japanese army. After Indonesian independence, these plantations were neglected, and the tea plants planted by the Dutch flourished again. Since then, the Jamus tea plantation was managed again by the Ngawi District Military Command in 1965. From 1973 until now, the Jamus tea plantation is managed by a private sector, namely PT Candi Loka. Jamus tea plantation is quite extensive. Namely, 478.2 ha, of which 418 ha are planted with tea, and 60.2 ha is planted with trees for reforestation. The land's geographical conditions in the Jamus tea plantation are suitable for developing a tea plantation business. The plantation's peaceful location with clear and cold springs accompanied by beautiful natural scenery is worthy of being a tourist attraction in the Ngawi district (Wijayanti 2020).

The culinary attraction in this tourist attraction is processed tea because the tea produced from the plantation is directly processed at the Candi Loka factory in the tea plantation area and is traditionally processed by the people around the Jamus Tea plantation. This tea factory also attracts tourists to process tea until it is ready to be marketed. PT Candi Loka facilitates tea processing educational tour packages. This educational tour is not equipped with a restaurant. A restaurant provides culinary processed tea in Indonesia, even though it can be a complete tour package. So far, visitors to the Jamus Tea Plantation tourism object can only enjoy processed tea in several stalls in the tourist area, even though there are quite a lot of visitors. Besides, there is no separate area for visitors to learn to make tea, or they still use another room for visitors to learn how to make tea. The reason that underlies the need for a place that can accommodate visitors to the Jamus Tea Plantation tourism object to enjoy processed Jamus tea directly from the plantation and accommodate visitors who want to learn how to make tea. This is in line with the idea of the previous head of management, who wanted a facility for visitors to enjoy processed tea from the Jamus tea plantation. The activities that can be accommodated by the design of this Candi Loka Restaurant will be as a dining area after being tired of walking around in the tea garden area, relaxing enjoying the view of the tea garden as well as being able to learn firsthand how to make tea, learn about types of tea and learn the history of the Jamus Tea garden.

Besides, visitors can also buy processed tea in the teashop area. Jamus tea batik motif is a motif inspired by the mountains' natural products in Jamus tea plantations. This motif consists of tea leaves and teak humps, which are distilled to form a geometric pattern. The interior design of Candi Loka Restaurant brings up a contemporary style (Zhu 2012). Contemporary style means a style that shows the present, something that is the same as the current time conditions or develops according to the present. A contemporary style room has a more dynamic and fresh impression, is free-form, modern, and unique. Therefore, this work aims to design Candi Loka Restaurant's interior by applying the Jamus Tea motifs batik theme and contributing as a reference for contemporary interior design based on local wisdom(Akmal 2011, 27).

\section{Method}

The interior design process for the Pluvio Huis restaurant in Bogor uses the Kurtz programming method, which has the Figure 1. 


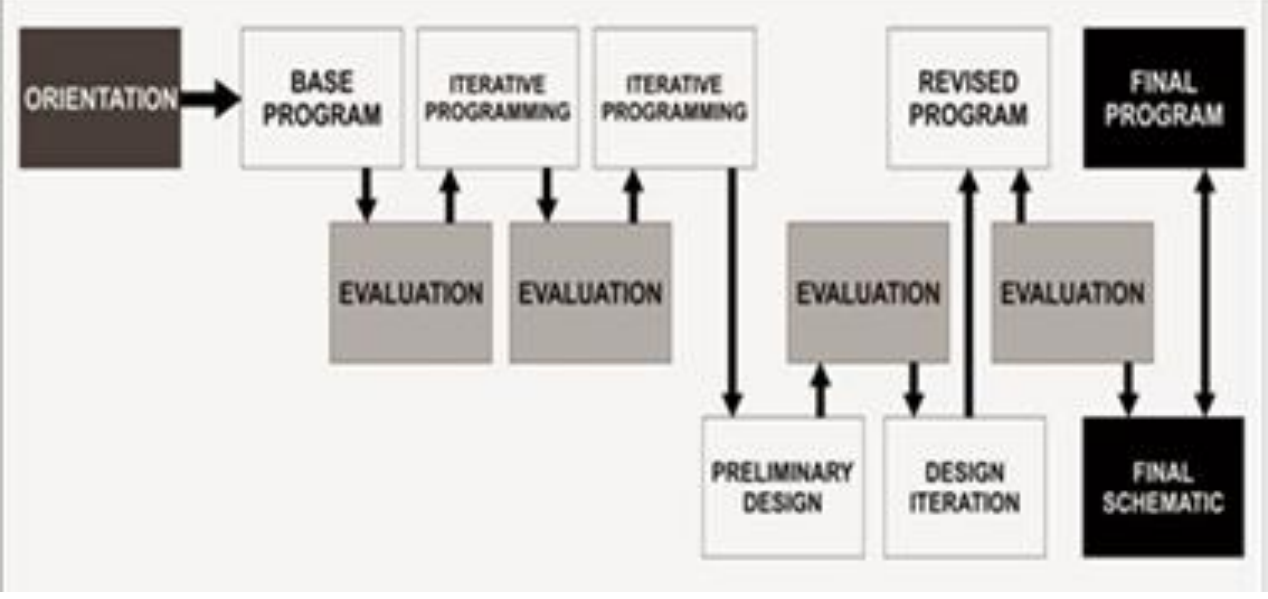

Fig. 1. The Kurtz Programming Method (Kurtz and Bah 2020)

- Orientation Stage

The stage of studying the philosophy, activities, and goals to be achieved with the client based on the client's results.

- Basic program stage.

The client needs an assessment stage, supporting literature, and initial program plans consisting of building organization, space organization, space area, and others.

- Programming repetition stage.

The designer stage presents the necessary program to the client, gets feedback from the client.

- The design stage.

The designer stage presents the initial schematic design to the client, which will be revised repeatedly until an agreement occurs between the designer and the client.

\section{Results and Discussion}

\subsection{Design Approach}

1) Functional Approach

According to specific criteria, the functional approach in designing an interior is to design space by considering space and user needs. These criteria include specific furniture grouping by activity, dimensions and workable space, adequate social distance, adequate visual and acoustic privacy, and adequate flexibility and adaptability. The Interior Design of Candi Loka Restaurant serves as a place that provides facilities for visitors to enjoy processed tea from the Jamus tea plantation. In line with this, Candi Loka Restaurant's design is intended to provide restaurant, educational, teashop, management offices, and service area facilities. In terms of fulfilling these functions, a building is needed to facilitate all activities that will occur in it. There are several areas in one building in this design, including the lobby area, restaurant area, office area, teashop area, workshop or education area, and service area.

\section{2) Ergonomic Approach}

Ergonomics is an applied science that studies human characteristics that need to be considered in designing a tool or system so that humans and objects can interact as effectively and safely as possible. The ergonomics discipline provides problem-solving in psychology and design user behavior in activities. In addition to anthropometric studies, ergonomic bases can also use sensing studies. Sensing study is a field of study on ergonomics closely related to human sensing problems, both the sense of sight, smell, and so on.

- In terms of smell, Candi Loka Restaurant uses the tea's aroma to attract visitors. 
- Judging from the vision / visual, at Candi Loka Restaurant, made one with nature. Glass walls supported them to enjoy the tea garden's beauty from inside the restaurant without being exposed to dust from outside.

- Judging from the furniture materials analysis, some furniture is made of wood to provide comfort for visitors because wood does not quickly transfer temperature, considering the tea plantations' temperature is quite cold.

\section{3) Aesthetic Approach}

Aesthetic science studies everything related to beauty, studying all aspects of what we call beauty (Djelantik, Rahzen, and Suryani 1999). Beauty is one of the elements considered in designing interior designs so that the aesthetic approach will be an inspiration to design elements in a restaurant interior. The aesthetic approach to this design uses a theme and style approach.

\subsection{Design Ideas}

1) Design theme

The theme of the interior design of Candi Loka Restaurant in Ngawi is the Batik Jamus Tea motif. Jamus tea batik motif is a motif inspired by the mountains' natural products in Jamus tea plantations. This motif consists of an arrangement of tea leaves and teak weeds distilled to form a geometric pattern. This motif was created by a batik designer from Ngawi who is also a batik craftsman in Ngawi. This batik motif tells the personal experience of Mr. Johanes, who is the designer. He wants to pour out the beauty and natural wealth of the Jamus tea garden in the Ngawi district. On the way of Mr. Johanes to the Jamus tea garden, he passed through a large teak forest. Nevertheless, unfortunately, the teak forests in Ngawi often experience illegal logging by irresponsible parties, so that the teak forests in Ngawi leave many teaks gnarled.

The surrounding community then uses the teak stump resulting from illegal logging to become products in furniture or other household necessities. Apart from being used alone, the processed teak weevils are also sold on the Ngawi district's roadside, especially in the Solo-Ngawi highway, the meeting hall, and skills training for forest farmer groups Banjarejo craftsmen. Even today, teak humps can become one of the superior products of Ngawi Regency that penetrate foreign markets. Mr. Johanes poured the story of the teak hump along the road to the Jamus tea garden into the Jamus Tea motif batik, which depicts the richness of the Jamus tea garden combined with teak weeds. The Jamus Tea batik pattern is carried out by stylizing the Jamus Tea batik motif elements (Figure 2).

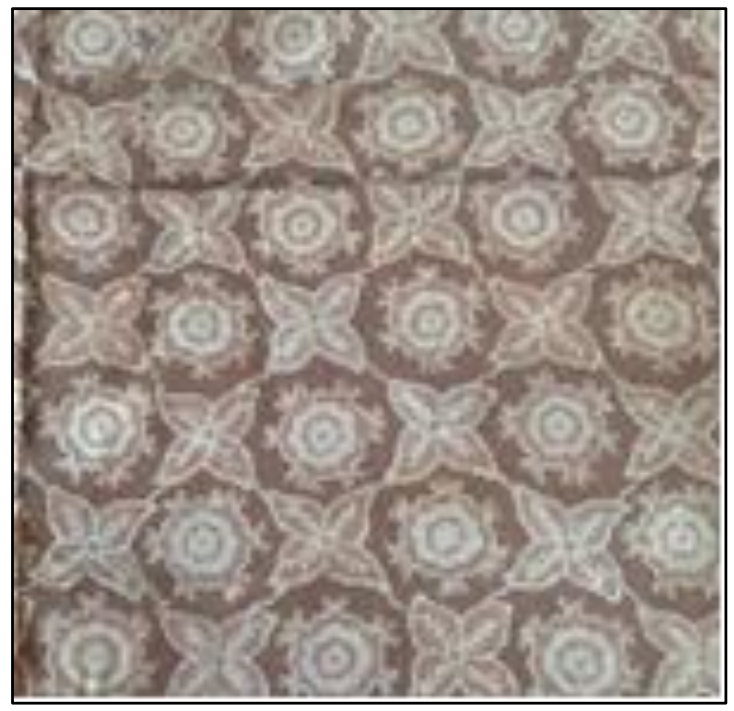

Fig. 2. Jamus Tea Motif Batik (Wijayanti 2020) 
Table 1. The Jamus Tea batik pattern is carried out by stylizing the elements in the Jamus Tea batik motif

Design Transformation
Dining table
The smooth table leg has sideways branches inspired by the leaf bones'
shape with straight lines and lateral branches.

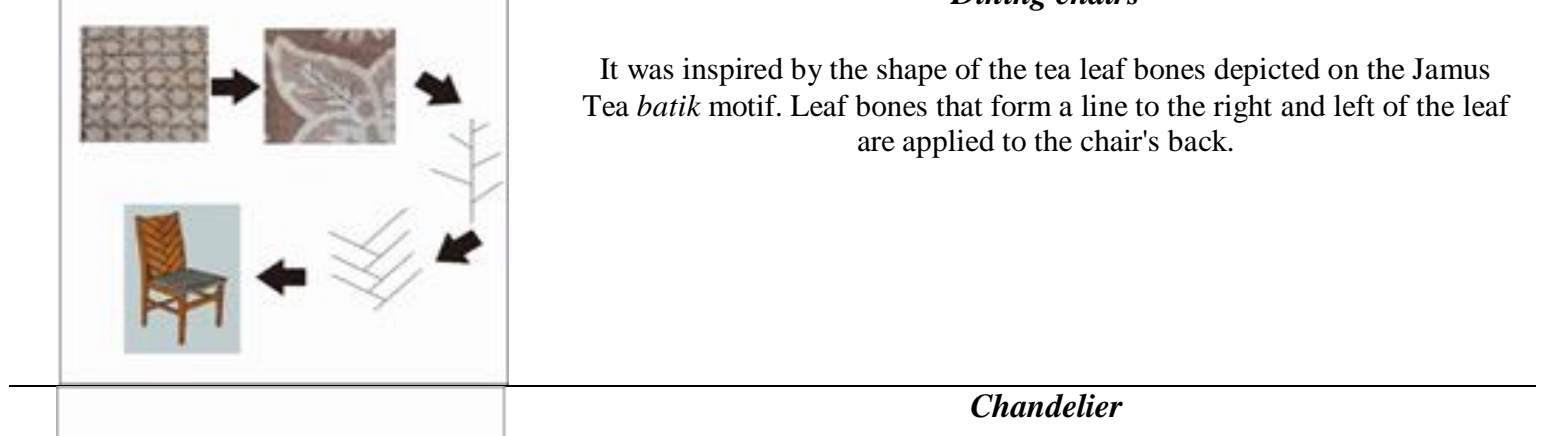

was inspired by the cross-section of teak bobs depicted on the Jamus Tea Batik motif. The lamp frame is made of iron, and the lampshade is made of tea wood.

\section{Mirror}

It is a decorative element that is installed in the office area so that the room looks wider. The mirror shape is transformed from the tea leaves and teak tubs found in the Jamus Tea Batik motif.

\section{Floor Pattern}

It is a form of floor pattern found in the lobby area. The floor pattern's shape is transformed from the tea leaves' shape and teak weeds found in the Jamus Tea Batik motif. 




\subsection{Design Style}

The interior design of Candi Loka Restaurant in Ngawi uses a contemporary style. The design process must harmonize shapes, colors, and materials to achieve a unified unity in realizing a contemporary style. This contemporary style applies neutral colors, namely white, black and gray, combined with natural color characters. The application and combination of natural and artificial materials are used with modern installation techniques, natural and artificial lighting effects, and lots of glass walls to create a more open atmosphere.

\subsection{Siteplan}

Candi Loka Restaurant's location selection is based on an easy-to-reach location for visitors to the Jamus Tea Plantation tourism object and strategy. In the Interior Design of Candi Loka Restaurant, it will be assumed that it will be in the tea plantation area before entering the Jamus Tea garden's agrotourism area. The reason for choosing the location was chosen because; (1) This location has a land area sufficient for the floor plan; (2) Located in the tourist area of Jamus Tea Plantation, which is part of the Ngawi district tourism development route, namely the Kenebejo Line; (3) The location can be reached from Central Java and East Java's direction so that access to the location is easy for visitors to visit. The location has a strategic location because it is close to other tourist objects; (4) Possible to become one of the culinary places for processed tea; (5) Has a beautiful view and cool air; (6) There are various types of tea plants, including rare teas, so they are the main attraction; (7) There is an educational tour of the Candi Loka tea factory, and the Jamus Tea agro-tourism, a tour package with Candi Loka Restaurant; (8) Raw materials and processing are in one area.

\subsection{Grouping dan Zoning}

Determination of grouping and zoning based on zones and grouping of spaces in many activities that have been planned. Then will be analyzed in order to determine the grouping of space (grouping and zoning space). The nature of space can be divided as follows: Color differences explain the application of zoning grouping or space division. The red color indicates a private area, the blue color indicates a public area, the green color indicates a semi-public area, and the yellow color indicates a service area. 


\subsection{Lay Out}

Layout arrangement and furniture refer to the nature of the space, activities, and circulation patterns in the design of Candi Loka Restaurant. The following is the layout of the Interior Design of Candi Loka Restaurant in Ngawi.

\subsection{Floor}

The use of floor patterns refers to the characteristics of contemporary styles and floor materials are adjusted to the regulation of the Minister of Health of the Republic of Indonesia number 304 / MENKES / PER / IV / 1989 concerning the health requirements of restaurants and restaurants which state that floors must be waterproof, flat, not slippery and easy to clean. These regulations are a consideration for choosing ceramics and parquet as materials for floors at Candi Loka Restaurant.

\subsection{Ceiling}

The use of ceiling patterns refers to the characteristics of contemporary styles. The ceiling material is adjusted to the regulation of the Minister of Health of the Republic of Indonesia number 304 / MENKES / PER / IV / 1989 regarding health requirements for and restaurants. The regulation states that the ceiling has a flat surface that is bright in color and easy to clean, there are no holes, and the ceiling height from the floor is at least 2.4 meters. Characteristic criteria are considered when choosing ceramics and parquet as materials for floors at Candi Loka Restaurant. The interior design of Candi Loka Restaurant in Ngawi is an effort to facilitate visitors' needs to the Jamus tea garden. Visitors can enjoy the processed Jamus tea in the dining area/restaurant after being tired of walking around the tea garden area, relaxing enjoying the view of the tea garden as well as being able to learn firsthand how to make tea, learn about the types of tea and learn the history of the Jamus tea garden in the workshop area and education. Besides, visitors can also buy processed tea in the teashop area. Candi Loka Restaurant's design in the Ngawi district used a functional, ergonomic, and aesthetic approach. These approaches are intended so that the design achieved is a design that is aesthetically pleasing and comfortable and functions optimally so that it can make it easier for people to do their activities in it. The ergonomic approach is concerned with user safety and comfort.

\section{Conclusion}

In this work, Candi Loka Restaurant's interior design carries a batik theme with the Jamus Tea motif. The theme was applied using a contemporary style in the design of Candi Loka Restaurant. This batik motif depicts the natural wealth of Ngawi Regency in the form of superior products from teak weeds and the wealth of Jamus tea gardens. The primary and aesthetic elements used are mostly the shapes and materials depicted on the Jamus Tea batik motif. This element is transformed into a new form but does not leave Teh Jamus batik's distinctive characteristic. The shape that is often the inspiration for creating new forms is the shape of the leaves both from the leaf bones and the leaves' sides, then the shape of the teak hump in the Jamus Tea batik motif. The materials used are mostly teak wood, one of Ngawi Regency's natural resources, both from the trunk and the stump. The dominant colors are green, which is inspired by the freshness of the Jamus tea leaves, and the brown teak hump, which is the hallmark of the Jamus Tea batik motif. These two colors are combined with neutral colors such as white, black or gray so that a contemporary style in this design can be created. The objects of working on the design are as follows: 1) Lobby as a means of information for visitors; 2) Dining area as a place to enjoy the menu ordered by visitors; 3) Teashop as a sales facility for Jamus tea products; 4) Kitchen as a place to process visitor's order menu; 5; Workshop and Education Area as a place for visitors who want to learn how to make tea and learn about history and types of tea; 6) The manager's work area which consists of a staff office, a meeting area, and a manager's room; and 7) Service area which includes warehouses, toilets, and prayer rooms.

\section{References}

Akmal, Imelda. 2011. Seri Rumah Ide: 80+ Rak Penyimpanan. Gramedia Pustaka Utama. 
Alatas, Alwi, and Wan Suhana Wan Sulong. 2020. "The Emergence and Development of Indigenous Tea Plantations in West Java, 1875-1941." KEMANUSIAAN The Asian Journal of Humanities 27 (2): 39-58. https://doi.org/10.21315/kajh2020.27.2.3.

Djelantik, Anak Agung Made, Taufik Rahzen, and Ni Nyoman Manik Suryani. 1999. Estetika: Sebuah Pengantar. Masyarakat Seni Pertunjukan Indonesia.

Hermawan, B, and A B Sholihah. 2020. "Cultural Heritage as City Identity Case Study of Ngawi, East Java, Indonesia." IOP Conference Series: Earth and Environmental Science 447 (March): 012040. https://doi.org/10.1088/17551315/447/1/012040.

Kurtz, Jannis, and Bubacarr Bah. 2020. An Integer Programming Approach to Deep Neural Networks with Binary Activation Functions. ArXiv Preprint Arxiv:2007.03326, issued 2020.

Pujiasmanto, B, I Aliyah, N Miladan, and Margana. 2021. "Development of Organic Agro Tourism for Optimizing Agricultural Resources in Ngawi, East Java, Indonesia." IOP Conference Series: Earth and Environmental Science 637 (January): 012061. https://doi.org/10.1088/1755-1315/637/1/012061.

Syahbudin, A, A Widyastuti, N W Masruri, and A Meinata. 2019. "Morphological Classification of Tea Clones ( Camellia Sinensis, Theaceae ) at the Mount Lawu Forest, East Java, Indonesia." IOP Conference Series: Earth and Environmental Science 394 (December): 012014. https://doi.org/10.1088/1755-1315/394/1/012014.

Wijayanti, Pradnyo. 2020. "Exploration of Ngawi Batik Ethnomatematics to Unlock Philosophy Values and Mathematics Concepts." Journal Intellectual Sufism Research (JISR) 3 (1): 26-37.

Zhu, Zhong Cui. 2012. "The Appearance and Support of Mind-Style Preference and Social Background of the Contemporary Interior Design." Advanced Materials Research 450-451 (January): 917-21. https://doi.org/10.4028/www.scientific.net/AMR.450-451.917. 